1 McFadden ER, Lyons HA. Arterial blood gas tension in asthma. $N$ Engl $¥$ Med 1968;278:1027-32.

2 Rebuck AS, Read J. Assessment and management of severe asthma. Am f Med 1971;51:788-98.

3 British Thoracic Society. Guidelines on the management of asthma. Thorax 1993;48:S1-24.

4 Clayton DG, Webb RK, Ralston AC, Duthie D, Runciman WB. Pulse oximeter probes. Anaesthesia 1991;46: $260-5$

5 Statement by the British Thoracic Society, Research Unit of the Royal College of Physicians of London, King's Fund Centre, National Asthma Campaign. Guidelines for the manament of asthma in adults: II - Acute severe asthma. BMf 1990;301:797-800.
6 Hutton $P$, Clutton-Brock $T$. The benefits and pitfalls in pulse oximetry. BMf 1993;307:457-8.

7 Rudolf M, Turner JA McM, Harrison BDW, Riordan JF, Saunders KB. Changes in arterial blood gases during and after a period of oxygen breathing in patients with chronic hypercapnic respiratory failure and in patients with asthma. Clin Sci Mol Med 1979;59:389-96.

8 West J. Respiratory physiology - the essentials. 4th edn. Baltimore: Williams and Wilkins, 1990: 69-85.

9 Ralston AC, Webb RK, Runciman WB. Potential errors in pulse oximetry. Anaesthesia 1991;46:202-6.

10 Pearson MG, Spence DPS, Ryland I, Harrison BDW. Value of pulsus paradoxus in assessing acute severe asthma. BMF 1993;307:659.

\title{
Non-tuberculous pulmonary infections in Scotland: a cluster in Lothian?
}

\author{
Friederike G E Böllert, Brian Watt, Andrew P Greening, Graham K Crompton
}

Respiratory Medicine Unit, Western General Hospital, Edinburgh EH4 2XU, UK

F G E Böllert

A P Greening

G K Crompton

Scottish Mycobacteria Reference Laboratory, Edinburgh EH10 5SB, UK

B Watt

Reprint requests to: Dr F G E Böllert.

Received 29 June 1994 Returned to authors 5 September 1994 Revised version received 17 October 1994 Accepted for publication 10 November 1994

\begin{abstract}
Background - A retrospective study was carried out to confirm the clinical impression that, in Lothian, non-tuberculous mycobacterial infections are as common as pulmonary tuberculosis.

Methods - All pulmonary isolates of Mycobacterium tuberculosis/bovis and nontuberculous mycobacteria in Scotland from April 1990 to March 1993, and the notes of all patients with $M$ malmoense isolates in Lothian, were reviewed. Information on mycobacterial culture procedures in Scottish laboratories was obtained as part of an audit project.

Results - Of all pulmonary isolates of mycobacteria in Lothian 53\% (108/205) were non-tuberculous strains compared with $18 \%(140 / 800)$ for Scotland outside Lothian. Although comparable in population size and laboratory techniques, Lothian (108) had almost twice as many isolates of non-tuberculous mycobacteria as Glasgow (56), but the proportions of $M$ malmoense and $M$ avium intracellulare complex were similar in both areas. Of 41 patients with $M$ malmoense isolates in Lothian 30 (75\%) had clinically significant lung disease; only one was HIV positive. Conclusions - Non-tuberculous mycobacteria pose an increasing clinical problem in Scotland as a cause of pulmonary disease. There is a cluster of cases with $M$ malmoense infection in Lothian which cannot be attributed to the high local prevalence of HIV.

(Thorax 1995;50:188-190)
\end{abstract}

Keywords: non-tuberculous mycobacteria, Mycobacterium malmoense, Lothian.

A review of all pulmonary mycobacterial isolates in Scotland over three years revealed that almost half of all Scottish isolates of $\mathrm{Myco-}$ bacterium malmoense were from patients in Lothian. $M$ malmoense was first described as a pulmonary pathogen in $1977^{1}$ but has since been reported in increasing frequency in Europe. $^{2-7}$ The organism has only rarely been isolated in the USA and from immunocompromised patients. $^{8-10}$ This study attempted to determine whether the clustering of patients with $M$ malmoense in Lothian was genuine or due to the use of different laboratory methods.

\section{Methods}

The names of all patients in Scotland with positive pulmonary isolates (sputum, bronchial washings, lung tissue, pleural fluid, and biopsies) of $M$ tuberculosis, $M$ bovis, and nontuberculous mycobacteria during the period April 1990 to March 1993 were obtained from the Scottish Mycobacteria Reference Laboratory in Edinburgh. Age, sex, postcode, HIV status, and details of antimycobacterial treatment for these patients were collected from general practitioners and consultant colleagues. Information on mycobacterial culture procedures in Scottish bacteriology laboratories was available through an audit project of the Reference Laboratory. In order to assess possible clustering of cases within Lothian we related the number of patients with $M$ malmoense strains to their postcode districts and the population figure of that area based on the 1991 census.

\section{Results}

All data concerning positive mycobacterial cultures represent pulmonary samples of patients which were received by the laboratories during the period April 1990 to March 1993. 


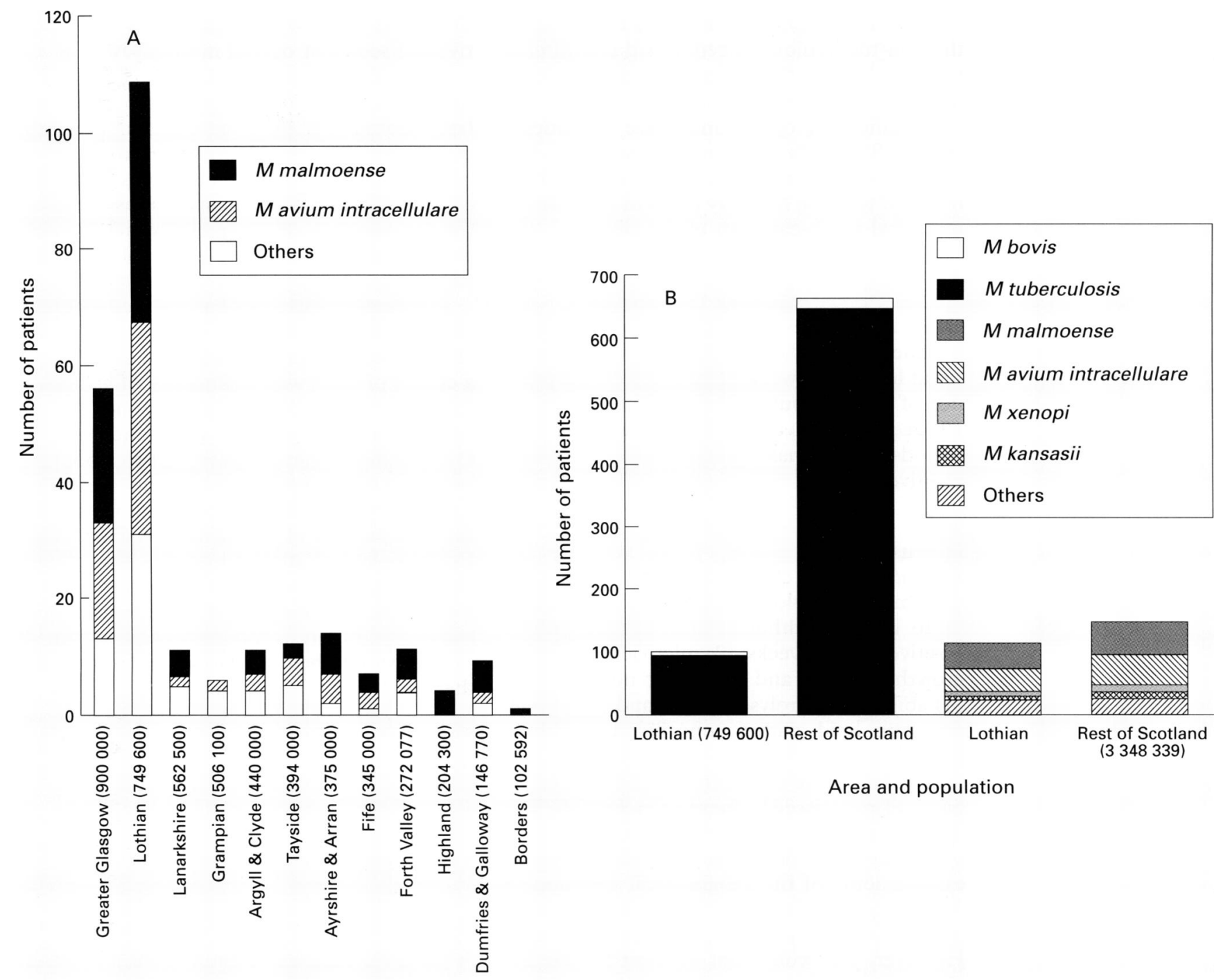

Health Boards and population

(A) Number of patients with pulmonary isolates of non-tuberculous mycobacteria from April 1990 to March 1993 (isted according to Health Boards in descending order of population size). (B) Number of patients with pulmonary isolates of $M$ tuberculosis/M bovis and non-tuberculous mycobacteria in Lothian and the rest of Scotland from April 1990 to March 1993.

\begin{abstract}
SCOTLAND OUTSIDE LOTHIAN (M TUBERCULOSIS/ BOVIS COMPARED WITH NON-TUBERCULOUS MYCOBACTERIA)

There were 800 mycobacterial isolates comprising $644 M$ tuberculosis, $16 \mathrm{M}$ bovis, and $140(18 \%)$ non-tuberculous mycobacteria $(M$ malmoense 54, $M$ avium intracellulare $46, M$ xenopi 11, $M$ kansasii 12 , and rapid growing mycobacteria 17) in Scotland outside Lothian. The number of patients from whom non-tuberculous mycobacteria were isolated for each health board and the numbers of patients with isolates of $M$ tuberculosis, $M$ bovis, and nontuberculous mycobacteria for Lothian and the rest of Scotland are shown in the figure.
\end{abstract}

LOTHIAN (M TUBERCULOSIS/BOVIS COMPARED WITH NON-TUBERCULOUS MYCOBACTERIA)

There were 205 mycobacterial isolates of which 93 were $M$ tuberculosis, four were $M$ bovis, and $108(53 \%)$ were non-tuberculous mycobacteria ( $M$ malmoense $41, M$ avium intracellulare 36, $M$ xenopi 9, $M$ kansasii 4, and rapid growing mycobacteria 18) in Lothian.

\section{LOTHIAN (M MALMOENSE)}

There was an even distribution of the 41 Lothian cases with $M$ malmoense isolates ( 24 men, 17 women, median age 58 years) during the three year period (16, 10, and 15 cases).

Thirty one patients had at least two positive cultures and in 20 the first culture positive sample was also film positive. Eleven patients were tested for HIV; 10 had a negative result and one patient had AIDS. ${ }^{8}$ Nine patients had their HIV status assessed as part of a research study and none had any risk factors for the virus.

Thirty of the 41 patients $(75 \%)$ received treatment with varying combinations of antimycobacterial drugs for a median period of 14 months by the end of March 1993. All of these patients fulfilled the diagnostic criteria of nontuberculous mycobacterial disease as listed by the American Thoracic Society. ${ }^{11}$ In all but one patient regimens included at least rifampicin plus ethambutol. Treatment is ongoing in 16 patients and was started in one patient after March 1993.

Ten of the patients treated died and in four (duration of treatment: $3,13,21$, and 27 
months) necroscopic examination revealed that the non-tuberculous infection had contributed to death. Three of these patients had additional infection with Aspergillus fumigatus. ${ }^{12}$

Identification of the incidence of patients (per 1000 population) with $M$ malmoense isolates in selected postcode districts in Lothian revealed that the majority of them lived in the semirural south-east part of the area.

MYCOBACTERIAL CULTURE TECHNIQUES

Of 20 laboratories which culture mycobacteria routinely $17(85 \%)$ incubated their specimens for at least eight weeks, five followed the practice of the Edinburgh Unit and incubated for 12 weeks, and five extended their incubation periods up to a maximum of 16 weeks for film positive samples.

\section{Discussion}

$M$ malmoense is characterised by (1) the requirement of prolonged incubation periods of up to 12 weeks although most cultures will be positive at eight weeks; (2) microaerophilia; (3) growth at $25^{\circ} \mathrm{C}$ and $37^{\circ} \mathrm{C}$ but not at $45^{\circ} \mathrm{C}$; (4) ability to hydrolyse Tween; and (5) a characteristic lipid pattern on thin layer chromatography. ${ }^{1}$

Colonies of the organism on solid media may be small and missed by inexperienced staff. The difference in mycobacterial procedures and lack of experience in detecting the organism might explain some of the geographical variation of $M$ malmoense isolates within Scotland, notably in areas where there were no positive cultures. However, this would not account for the increased number of $M$ malmoense isolates in Lothian compared with Glasgow, as the laboratory techniques were comparable.

Although our data for Scotland refer to pulmonary isolates of $M$ malmoense which, in some cases, might represent casual contamination or colonisation rather than disease, the available literature ${ }^{613}$ suggests that about $80 \%$ of isolates of $M$ malmoense are clinically significant. This would result in 43 of the 54 cases $(80 \%)$ in Scotland outside Lothian and a total figure of 73 cases (43 cases in Scotland outside Lothian plus 30 cases in Lothian) for the whole of Scotland from 1990 to 1993, which is more than a threefold rise in incidence compared with that quoted by France et al. ${ }^{5}$

Some clustering of cases was detected within the south-east of Lothian. The gross incidence does not take into account factors such as age distribution and environmental influences, but there was no obvious correlation with deprivation scores or overall mortality.

The natural reservoir for $M$ malmoense is unknown, although the organism has been isolated from fresh water in Finland (personal communication, Katila) and from stools of healthy individuals. ${ }^{14}$ All households in Lothian postcode areas receive their water as a mixture from a number of reservoirs which renders water contamination as a cause of clustering unlikely.

In summary, this study has revealed that nontuberculous mycobacteria pose an increasing clinical problem in Scotland, and that there is a cluster of cases with pulmonary $M$ malmoense infections in Lothian which cannot be attributed to the high local prevalence of HIV. Our findings might relate in part to laboratory practice and experience in the Reference Laboratory, though this does not hold true for the comparison of Glasgow and Edinburgh. Epidemiological studies into the possible environmental habitat of $M$ malmoense, documentation and follow up of all patients with $M$ malmoense isolates, and molecular typing of isolates should help to clarify our findings further

We would like to thank all consultants in respiratory medicine and infectious diseases, five general practitioners, and Gillian Harris and Alan Rayner from the Mycobacteria Reference Laboratory for their cooperation with this study.

1 Schröder KH, Juhlin I. Mycobacterium malmoense sp nov. Int $\mathcal{F}$ Systematic Bacteriol 1977;27:241-6.

2 Yates $\mathrm{MD}$, Grange JM, Collins $\mathrm{CH}$. The nature of mycobacterial disease in south-east England, 1977-84. F Epidemiol Community Health 1986;40:295-300.

3 Jenkins PA. Mycobacterium malmoense. Tubercle 1985;66:193

4 Jenkins PA, Tsukamura $M$. Infections with Mycobacterium malmoense in England and Wales. Tubercle 1979;60:71-6.

France AJ, McLeod DT, Calder MA, Seaton A. Mycobacterium malmoense in Scotland: an increasing problem. bacterium malmoense in

6 Katila M-L, Viljanen T, Brander E. $M$ malmoense infections. Z Erkrank Atm Org 1991;176:159-61.

7 Portaels F, Denef M, Larsson L. Pulmonary disease caused by Mycobacterium malmoense. Comments on the possible origin of infection and methods of laboratory diagnosis. Tubercle 1991;72:218-22.

8 Willcocks L, Leen CLS, Brettle RP, Rayner A, Harris G, Watt B. Isolation of $M$ malmoense from HIV positive patients. F Infect 1993;26:345-6.

9 Alberts WM, Chandler KW, Solomon DA, Goldman AL. Pulmonary disease caused by Mycobacterium malmoense. Am Rev Respir Dis 1987;135:1375-8.

10 Crellin AM, Owen JR. Disseminated Mycobacterium malmoense infection. Unreviewed reports. BMF 1984; 289 . 734 .

11 American Thoracic Society. Diagnosis and treatment of disease caused by nontuberculous mycobacteria. $\mathrm{Am} R e$ Respir Dis 1990;142:940-53.

12 Böllert FGE, Sime PJ, MacNee W, Crompton GK. Pulmonary Mycobacterium malmoense and aspergillus infection: a fatal combination. Thorax 1994;49:521-2.

13 Banks J, Jenkins PA, Smith AP. Pulmonary infection with $M$ malmoense - a review of treatment and response. Tubercle 1985;66:197-203.

14 Portaels F, Larsson L, Smeets P. Isolation of mycobacteria from healthy persons' stools. Int 7 Lepr 1988;56:568-71. 